\title{
Mapping of Maize Growing Period over the Free State Province of South Africa: Heat Units Approach
}

\author{
Mokhele Edmond Moeletsi ${ }^{1,2}$ \\ ${ }^{1}$ Agricultural Research Council, Institute for Soil, Climate and Water, Private Bag X79, Pretoria 0001, South Africa \\ ${ }^{2}$ Risks and Vulnerability Assessment Center, University of Limpopo, Private Bag X1106, Sovenga 727, South Africa \\ Correspondence should be addressed to Mokhele Edmond Moeletsi; moeletsim@arc.agric.za
}

Received 16 December 2016; Accepted 23 February 2017; Published 19 March 2017

Academic Editor: Herminia García Mozo

Copyright (C) 2017 Mokhele Edmond Moeletsi. This is an open access article distributed under the Creative Commons Attribution License, which permits unrestricted use, distribution, and reproduction in any medium, provided the original work is properly cited.

\begin{abstract}
Temperature is one of the important environmental parameters that determines the development of a crop from one stage to another. It is integral in the calculation of heat units. In this study, the thermal index concept is used to determine the length of the growing period of short season, medium season, and medium-late season maize crop varieties for different sowing dates (1st dekad of October to 1st dekad of January). The results show high spatiotemporal variation in the median growing period for all three maize varieties. The length of the growing period for the short, medium, and medium-late season varieties is relatively short during October to early December with values in some areas of less than 100, 120, and 120 days, respectively. The duration of the planting period increases exponentially in most places starting from the 2nd dekad of November to 2nd dekad of December, depending on the region and crop variety. Long growing periods are likely to align maize growing period with dates of high frost risk and water shortages. Thus, appropriate choice of sowing date taking into consideration the thermal time requirements of the cultivar is crucial for proper growth and development of the maize crop.
\end{abstract}

\section{Introduction}

Weather and environmental conditions during the growing period of the crop have a direct bearing on plant growth and development and hence ultimately affect the crop yield [1]. Gordon and Bootsma [2] and Olivier and Annandale [3] described growth as an increase in crop mass, height, and volume over a certain period while development is the timing of the crop phenology from one stage to another. Photoperiod and temperature are the main environmental conditions that affect the plant development but modern hybrid maize plants respond more to temperature and are less dependent on photoperiod [4-6]. Plant growth is caused by interactions of different environmental conditions at optimum temperatures while crop development is directly affected by temperature changes $[2,7]$.

The period that a plant takes to complete a particular growth stage is directly related to temperature and particularly sums of daily temperatures [8]. Brown and Bootsma [9] stated that cool temperatures tend to slow down the growth while warm temperatures hasten maturity. This led to air temperature based indices like growing degree days (GDD), photothermal units, phenothermal index, and heat use efficiency being used in determining phenological characteristics of crops $[8,10]$. The concept of thermal index or heat units commonly measured in GDD was first introduced in 1730 by Reanumur $[11,12]$. Heat units are mostly defined as the amount by which mean daily temperature exceeds a certain base temperature $[5,11,13,14]$. Thermal index is based on the assumption that the actual time to attain phenological stage is linearly related to the temperature range between base temperature $\left(T_{b}\right)$ and optimum temperature $[10,12,15]$. The base temperature for the maize crop is $10^{\circ} \mathrm{C}$ and, at this temperature and below, the rate of crop development is zero. Base temperatures differ for each plant species and the choice of appropriate temperature is core towards better modelling of their growth and development [6].

Determination of the timing of phenological stage and maturity of crop cultivars in different environments is a crucial exercise that will enable the matching of cultivars 
using lengths of growing period to particular areas and sowing dates that will ensure optimum production [16]. It makes agronomic sense to represent crop development period in terms of heat units as compared to the number of days because climate conditions in one locality might cause the crop to mature early while in others maturity might be delayed. The crop will not always need the same number of days to reach maturity or another development stage but it will always need the same heat unit requirements [3]. Plants can withstand a certain temperature threshold and for better representation of crop development some calculations of thermal time incorporate the upper threshold temperature in which a crop can survive $[11,17]$. Thus, thermal indices can be helpful to farmers in assisting them to select the hybrids and varieties that are suitable to their area [9]. The plant needs certain heat requirements for each stage and it cannot develop from one stage to the next advanced stage without receiving the necessary heat units [6]. The GDD can also be used to predict phenological events like expected date of flowering, maturity, or harvesting $[11,14,18]$.

The objective of this study is to determine the temporal and spatial variability of the number of days for the attainment of heat units required from planting to maturity of three different maize varieties (short, medium, and medium-late season) in the Free State Province of South Africa for different planting dekads starting in October to early January.

\section{Data and Methods}

2.1. Data. Meteorological data consisting of daily minimum and maximum temperatures were obtained from the Agricultural Research Council (ARC) Agroclimate Database, the South African Weather Service (SAWS), and the Lesotho Meteorological Services (LMS). The stations used in the analysis are shown in Figure 1 . A $90 \mathrm{~m} \times 90 \mathrm{~m}$ resolution altitude raster was obtained from the ARC GIS database.

2.2. Methodology. Methods used in calculating seasonal heat units are outlined in Section 2.2.1 while Section 2.2.2 will show the methods used to determine the growing periods for different planting dates and for different varieties.

2.2.1. Calculation of Heat Units. The heat units data was calculated on a daily basis using

$$
\mathrm{GDD}=\left[\frac{\left(T_{\max }+T_{\min }\right)}{2}\right]-T_{b},
$$

where $T_{\max }, T_{\min }$, and $T_{b}$ are daily maximum temperature, daily minimum temperature, and base temperature $\left(10^{\circ} \mathrm{C}\right)$, respectively.

The important condition for (1) is as follows: if $\left[\left(T_{\max }+\right.\right.$ $\left.\left.T_{\min }\right) / 2\right]<T_{b}$, then $\left[\left(T_{\max }+T_{\min }\right) / 2\right]=T_{b}$.

2.2.2. Growing Period. The daily heat units data were ordered in agricultural years starting on 1st July and ending on 30th June the following year. The number of days to attain short season (1340GDD), medium season (1420GDD), and medium-late season (1480GDD) variety seasonal heat units was calculated for all the stations in all the years $[19,20]$.
These values represented the growing period needed for the maize to reach maturity not considering factors like frost, availability of water, or any other factors affecting plant growth and development. The planting dates considered in the investigation start in the first dekad of October and end in the first dekad of January, representing ten different planting periods. The analysis is done on a dekadal basis (10 days) whereby a month is divided into three dekads. In the first, second, and third dekads, planting is considered to be on 5th, 15th, and 25th, respectively, in this study. The first two dekads have 10 days and the last dekad can have 8 to 11 days depending on the month and year.

2.2.3. Statistical Analysis and Mapping. All the time series data on the length of growing periods for short, medium, and medium-late maize varieties were then tested for normality using the Rainbow program. 50\% probability of nonexceedence value was determined for all the stations at each planting period and maize variety. In this study, 50th percentile values showing the return period of 1 in 2 years values were analyzed because the median or average value is found to be used by many farmers or advisors in planning the agricultural season.

Regression between the 50\% nonexceedence probability values for each station, maize variety, and sowing/planting date was done against the altitude for interpolation purposes. Previous studies show a relatively good relationship between the temperature indices and altitude [21]. The curve estimation of different indices was performed by SPSS statistical software using the following models: linear, quadratic, cubic, exponential, logarithmic, $S$-curve, inverse, and growth models, illustrated in (2) to (9), respectively.

Linear model is

$$
y=b_{1} * \text { alt }+c
$$

Quadratic model is

$$
y=b_{2} * \operatorname{alt}^{2}+b_{1} * \text { alt }+c .
$$

Cubic model is

$$
y=b_{3} * \mathrm{alt}^{3}+b_{2} * \mathrm{alt}^{2}+b_{1} * \text { alt }+c
$$

Exponential model is

$$
y=c * \exp \left(b_{1} * \text { alt }\right) .
$$

Logarithmic model is

$$
y=b_{1} * \ln (\text { alt })+c .
$$

$S$-curve model is

$$
y=\exp \left(\frac{b_{1}}{\text { alt }}+c\right) .
$$

Inverse model is

$$
y=\frac{b_{1}}{\text { alt }}+c .
$$




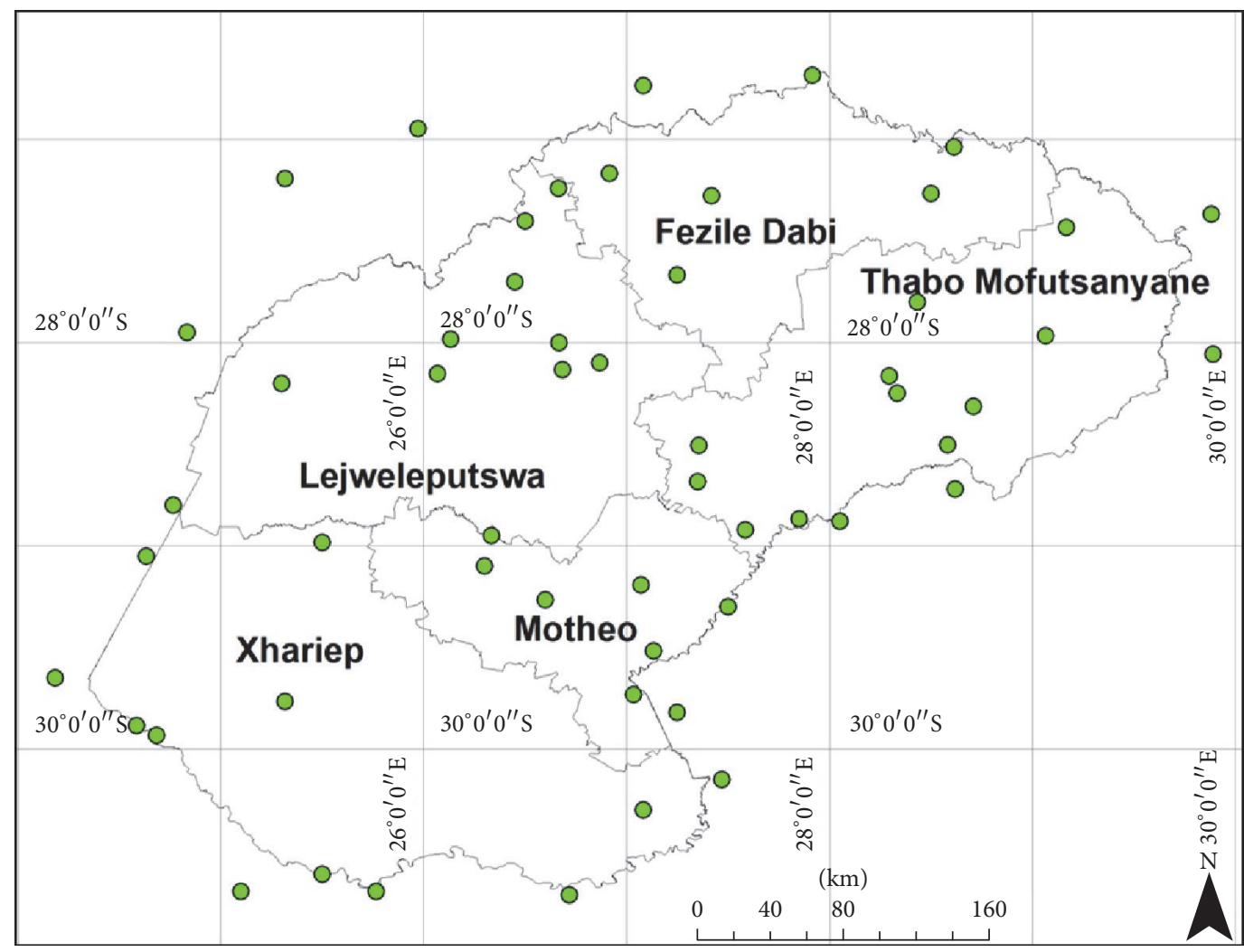

FIGURE 1: Spatial distribution of climate stations used in maize heat units assessment over the Free State Province of South Africa.

Growth model is

$$
y=\exp \left(b_{1} * \text { alt }+c\right)
$$

where $y$ is the growing period estimate, alt is the altitude, and $b_{1}, b_{2}, b_{3}$, and $c$ are constants.

The results of this regression analysis were used to create maps using the raster calculator imbedded in ArcGiS 9.3 software.

\section{Results and Discussion}

3.1. Growing Period. Table 1 shows the equation and $R^{2}$ obtained in the regression analysis between growing period days for short, medium, and medium-late season varieties against altitude in the Free State. The models that resulted in better correlation between the two parameters are mostly linear, quadratic, and exponential and $R^{2}$ was mostly over 0.80 , with exceptions occurring after the 2 nd dekad of November. High correlation values give more confidence in the created maps in Section 3.2 but careful consideration to areas in the values and mountainous places where the models might under/overestimate the lengths of the growing periods [22]. Coefficients of determination $\left(R^{2}\right)$ for the growing periods from the 3rd dekad of November are mostly over 0.75 , implying that over $75 \%$ of the variation of the growing period days is caused by variation in altitude. The lowest $R^{2}$ value of 0.67 is obtained in the 1st dekad of January planting. This low value is attributed to the fact that planting in January extends the growing period to the winter season, increasing the number of days to achieve heat requirements to very high values (exceeding 250 days in places), especially at altitudes higher than $1300 \mathrm{~m}$, as opposed to the western parts where altitude is less than $1200 \mathrm{~m}$ and growing season periods of around 150 days are attained.

3.2. Growing Period Maps. The lengths of the growing period for short, medium, and medium-late season varieties are presented for planting dekads starting from the 1st dekad of October to the 1st dekad of January.

3.2.1. Short Season Maize Variety. From the 1st dekad of October to 3rd dekad of December, a short season maize variety can grow for a period of less than 120 days based on the $50 \%$ risk (median) level for most places over the west and southwestern parts of the province (most parts of Lejweleputswa and northwestern Xhariep districts) (Figure 2). But planting maize in October or earlier over these parts of the province under rainfed farming would be risky due to the fact that onset of rains occurs in November [22,23]. Thus germination and early growth and development of the crop might be severely hampered. Beyond the 3rd dekad of December, the growing period increases exponentially to over 200 days from the 2nd dekad of January onwards, as illustrated by Figure 3 (Bothaville station). This is mainly attributed to slow rate of development in the months of March and April due to low temperatures [24]. The areas of shortest growing period are over the northwestern parts where planting a short 


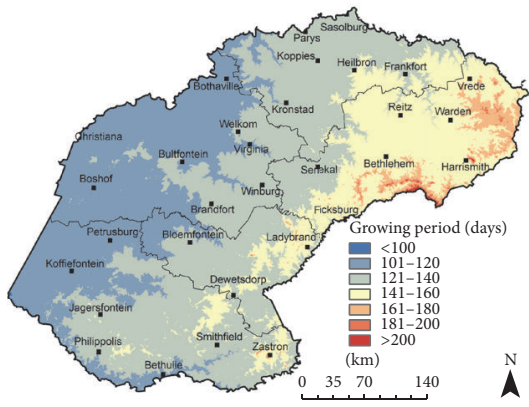

District municipalities - Towns

(a)

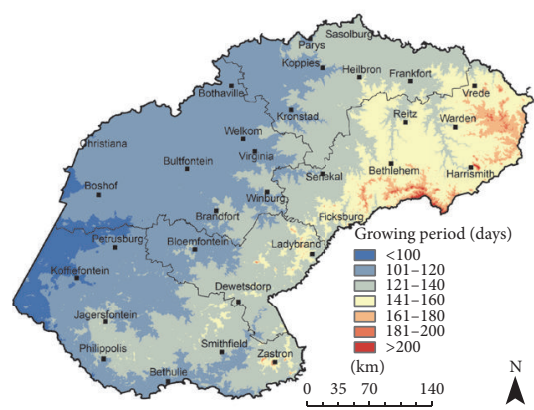

$\square$ District municipalities

- Towns

(d)

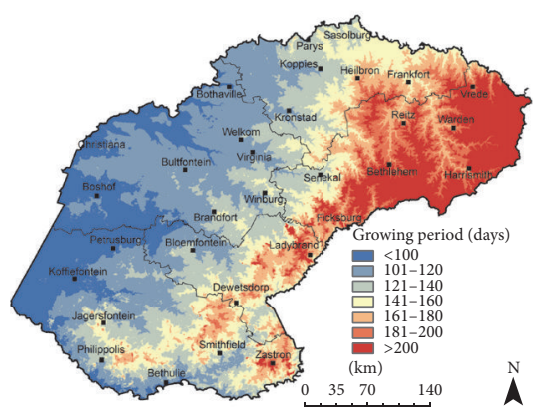

$\square$ District municipalities

- Towns

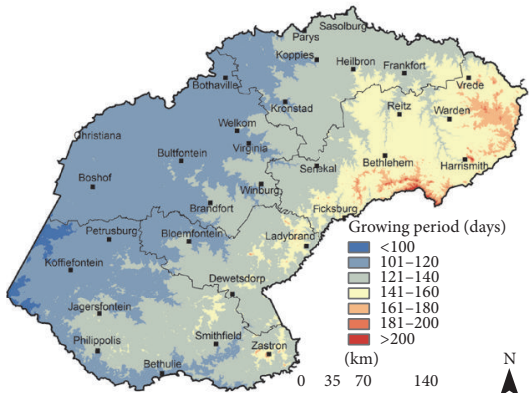

$\square$ District municipalities

- Towns

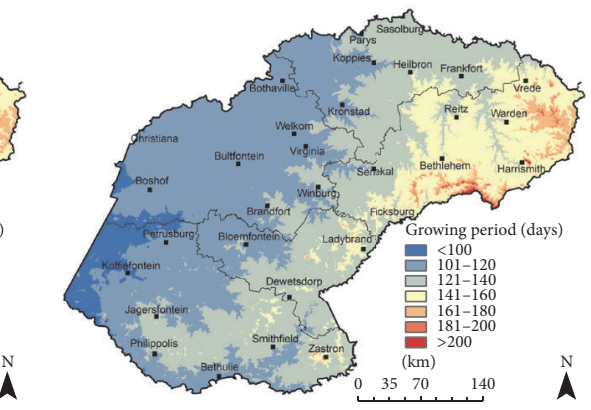

$\square$ District municipalities

- Towns (b)

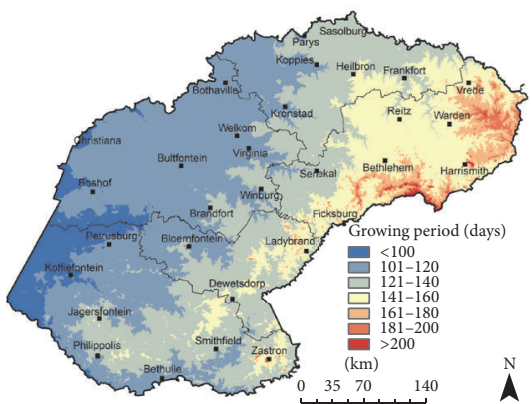

$\square$ District municipalities

- Towns

(e)

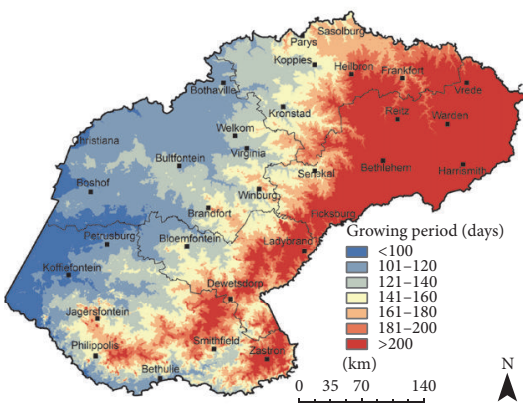

$\square$ District municipalities

- Towns

(h)

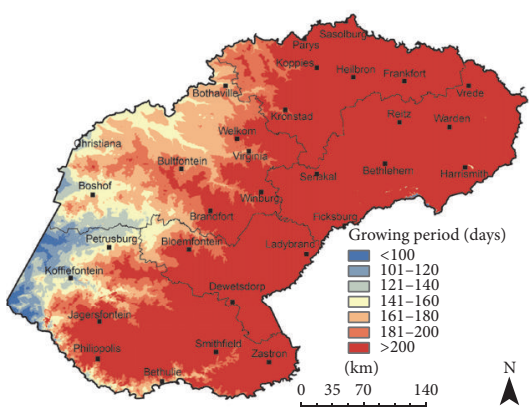

$\square$ District municipalities

- Towns (c)

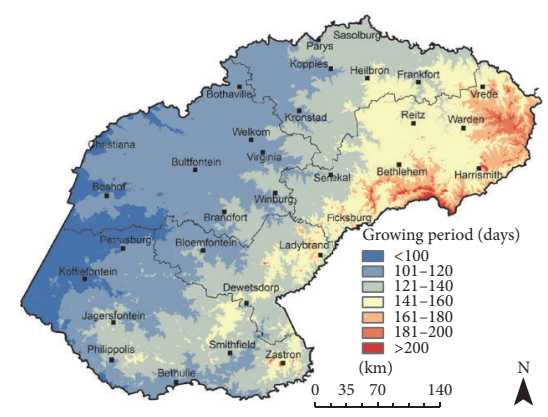

$\square$ District municipalities

- Towns

(f)

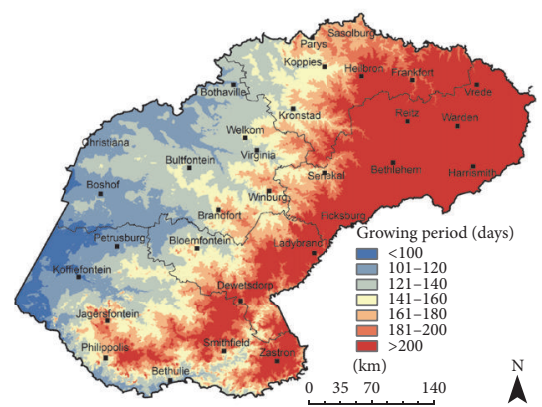

$\square$ District municipalities

- Towns

(i)

(j)

FIGURE 2: Growing period in days at $50 \%$ nonexceedence probability for a short season maize variety planted in the (a) 1st dekad of October, (b) 2nd dekad of October, (c) 3rd dekad of October, (d) 1st dekad of November, (e) 2nd dekad of November, (f) 3rd dekad of November, (g) 1st dekad of December, (h) 2nd dekad of December, (i) 3rd dekad of December, and (j) 1st dekad of January. 


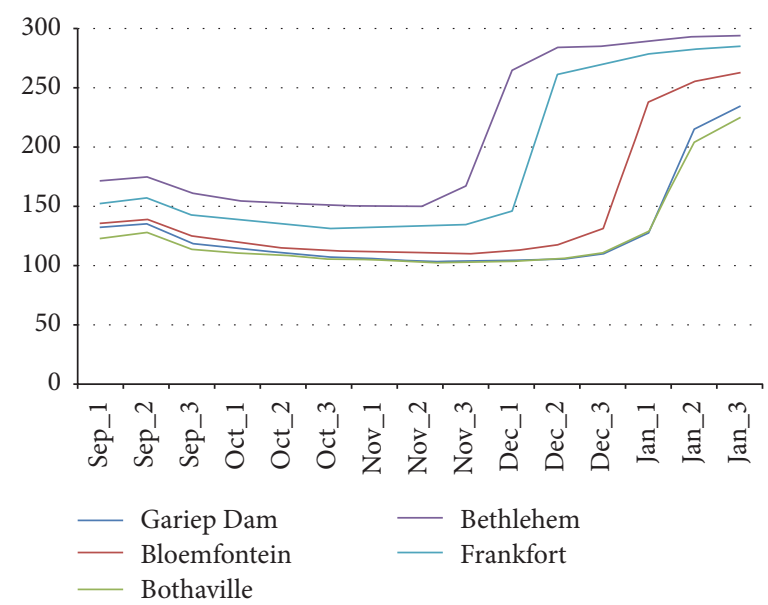

FIGURE 3: Length of growing period in days for a short season maize variety for the Gariep Dam, Bloemfontein, Bothaville, Bethlehem, and Frankfort stations from the 1st dekad of September to 3rd dekad of January.

TABLE 1: Equations and $R^{2}$ values for the regression between $50 \%$ nonexceedence probability of growing period against altitude in the Free State for short (S), medium (M), and medium-late (ML) season varieties.

\begin{tabular}{|c|c|c|c|}
\hline Planting dekad & Variety & Regression equation & $R^{2}$ \\
\hline \multirow{3}{*}{ October 1st dekad } & $\mathrm{S}$ & $y=0.0854 *$ alt +5.493 & 0.85 \\
\hline & M & $y=50.865 * \exp (0.000675 *$ alt $)$ & 0.85 \\
\hline & ML & $y=3.909 E-05 *$ alt $^{2}-0.01572 *$ alt +80.537 & 0.84 \\
\hline \multirow{3}{*}{ October 2nd dekad } & S & $y=0.0883 *$ alt -2.227 & 0.85 \\
\hline & M & $y=46.870 * \exp (0.0007137 *$ alt $)$ & 0.86 \\
\hline & ML & $y=47.440 * \exp (0.0007297 *$ alt $)$ & 0.85 \\
\hline \multirow{3}{*}{ October 3rd dekad } & S & $y=0.0919 *$ alt -9.755 & 0.85 \\
\hline & M & $y=43.468 * \exp (0.000752299 *$ alt $)$ & 0.86 \\
\hline & ML & $y=44.655 * \exp (0.0007580 *$ alt $)$ & 0.86 \\
\hline \multirow{3}{*}{ November 1st dekad } & S & $y=0.0976 *$ alt -18.439 & 0.83 \\
\hline & M & $y=41.249 * \exp (0.0007875 *$ alt $)$ & 0.86 \\
\hline & ML & $y=41.590 * \exp (0.0008110 *$ alt $)$ & 0.84 \\
\hline \multirow{3}{*}{ November 2nd dekad } & S & $y=0.1146 *$ alt -41.235 & 0.81 \\
\hline & $\mathrm{M}$ & $y=35.882 * \exp (0.0008922 *$ alt $)$ & 0.84 \\
\hline & ML & $y=31.147 * \exp (0.001031 *$ alt $)$ & 0.73 \\
\hline \multirow{3}{*}{ November 3rd dekad } & $\mathrm{S}$ & $y=0.1222 *$ alt -52.413 & 0.83 \\
\hline & M & $y=18.242 * \exp (0.001407 *$ alt $)$ & 0.75 \\
\hline & ML & $y=15.143 * \exp (0.001586 *$ alt $)$ & 0.79 \\
\hline \multirow{3}{*}{ December 1st dekad } & S & $y=11.389 * \exp (0.0017 *$ alt $)$ & 0.78 \\
\hline & $\mathrm{M}$ & $y=10.255 * \exp (0.001879 *$ alt $)$ & 0.82 \\
\hline & ML & $y=11.191 * \exp (0.001855 *$ alt $)$ & 0.82 \\
\hline \multirow{3}{*}{ December 2nd dekad } & $\mathrm{S}$ & $y=8.5352 * \exp (0.002 *$ alt $)$ & 0.82 \\
\hline & $\mathrm{M}$ & $y=10.106 * \exp (0.001945 *$ alt $)$ & 0.82 \\
\hline & ML & $y=12.139 * \exp (0.001863 *$ alt $)$ & 0.82 \\
\hline \multirow{3}{*}{ December 3rd dekad } & S & $y=9.203 * \exp (0.002 *$ alt $)$ & 0.83 \\
\hline & M & $y=-0.0002946 *$ alt $^{2}-1.193 *$ alt -890.635 & 0.73 \\
\hline & ML & $y=-0.0004254 * \mathrm{alt}^{2}+1.550 *$ alt -1115.334 & 0.68 \\
\hline \multirow{3}{*}{ January 1st dekad } & $\mathrm{S}$ & $y=-9.101 E-08 *$ alt $^{2}+0.898 *$ alt -793.45 & 0.70 \\
\hline & $\mathrm{M}$ & $y=-0.0005235 *$ alt $^{2}+1.787 *$ alt -1232.216 & 0.75 \\
\hline & ML & $y=-0.0005185 *$ alt $^{2}+1.713 *$ alt -1125.949 & 0.67 \\
\hline
\end{tabular}


season variety can take up to 100 days from the 2 nd dekad of October to 3rd dekad of December sowing dates. These areas have relatively high rates of heat unit accumulation $[21,22]$. Expected maturity dates (February to March for most parts) for planting short season maize in most areas over the Free State, especially for sowing periods from October to December, fall within the main rainfall season making this growing period less vulnerable to water deficiencies [23]. Most areas over the west and southwestern Free State experience a short rainy season and low rainfall amounts which makes planting of maize impossible unless under irrigation. Thus although these areas have a shorter growing period they are not desirable for rainfed maize production [22].

Over the far eastern and northeastern parts of the province the growing period is mostly longer than the other regions with values between 141 and 160 days from the 1st dekad of October to the 2nd dekad of November planting dates (Figure 2). Bethlehem and Frankfort stations in Figure 3 show that sowing dates for areas in the north, eastern, and northeastern places have short windows for planting short season maize as compared to other areas, mostly from October to November due to high incidences of frost before October [24, 25]. Growing periods in some of the high-lying areas in the same period exceed 200 days; these areas are not suitable for planting maize at any time of the year as they are susceptible to frost incidences throughout the growing period. Sowing dates occurring in December onwards mostly have growing periods exceeding 160 days (Figures 2 and 3). Over 160 days to maturity implies that maturity can be as late as early June which is outside the main agricultural season and the period from May onwards is vulnerable to high climate hazards.

3.2.2. Medium Season Maize Variety. The length of the growing period shows a lot of spatial variation with a southwest to northeast gradient for all the maize varieties (Figures 2, 4 , and 6). The lowest growing periods are over the west and southwest of the Free State Province (areas west of and around Koffiefontein, Petrusburg and Boshof), increasing gradually to the east and northeast and peaking over the northeastern Free State (east of Bethlehem, Harrismith, Warden, and Vrede). This shows that the rate of heat units accumulation is lowest in the north and northeast and highest over the western parts of the Province.

Over the western parts most areas have a growing period for a medium season maize variety ranging from 101 to 120 days from the 1st dekad of October to 3rd dekad of November, except patches over the far western and southwestern district where the length of the growing period for the medium season variety is comparatively short (less than 100 days) (Figure 4). This period of shorter lengths can extend to the $3 \mathrm{rd}$ dekad of December depending on the location (Figures 4 and 5). Beyond the 3rd dekad of November the growing period increases dramatically to over 200 days from the 2nd dekad of December onwards. The area extending from Philippolis over the southern parts to Sasolburg in the far northern region (including Bloemfontein, Winburg, Kroonstad, and Koppies) mostly has growing periods for a medium season maize variety between 121 and 140 days from the 1st dekad of October to 2 nd dekad of November (Figures 4 and 5). The longest growing periods are experienced over the eastern and northeastern regions where growing period for the medium season variety planted in the 1st dekad of October onwards exceeds 140 days (Figures 4 and 5). Other areas with long growing periods are over the southeastern parts. Growing periods of over 150 days cause the grain-filling and maturity stages of the crop to be in the months of May onwards which have low temperatures thus affecting the grain quality and can result in underdeveloped grains. Over the Free State frost onset is mostly in May onwards while the cessation of rains is also mainly in April or May [25]. Thus the growing periods for a medium season maize variety have lower chances of being subjected to climate hazards that can hamper the growth and development of the crop in western parts in most sowing dates while areas over the eastern and northeastern parts have a short sowing window (Figure 5).

3.2.3. Medium-Late Maize Variety. As for the medium-late season maize variety, the growing period in most parts of the Free State Province is less than 140 days for the sowing period starting from the 1st dekad of October to 2nd dekad of November (Figures 6 and 7). The lowest growing periods are attained over the western parts with periods of less than 120 days for the medium-late variety from the 1st dekad of October to 1st dekad of December. Over the eastern and northeastern areas (vicinity of Bethlehem, Harrismith, Vrede, and Warden) the growing period exceeds 160 days while places over the valleys and towards the central sites can have relatively shorter growing periods ranging from 141 to 160 days with a few patches of less than 140 days (Figure 6). Medium-late season varieties planted in November in most of the eastern, southeast, and some central parts have high chances of not reaching full maturity due to frost incidences during the months of April and May. The chances of the maize crop being affected by soil water shortages are also high [23]. Thus medium-late season varieties are highly vulnerable to climate risks like frost and water deficiency in some parts of the Free State Province especially when planted in November onwards.

\section{Conclusions and Recommendations}

Growing period for short, medium, and medium-late season maize varieties shows a good agreement with altitude over the Free State Province of South Africa. The linear regression models using altitude as the independent variable during the different sowing dates resulted in correlations mostly exceeding $90 \%$. The growing period for all the planting dekads and varieties mostly showed a northeast to southwest gradient with relatively short periods over the southwestern parts of the province (an area extending from the border of Lejweleputswa and Xhariep district to the southwest of Koffiefontein) and increasing gradually to peak over the northeastern parts of the province (highlands over the Thabo Mofutsanyane district). These areas are attributed to low heat accumulation and other areas of relatively low heat energy are eastern Motheo and eastern Fezile Dabi districts [22]. 


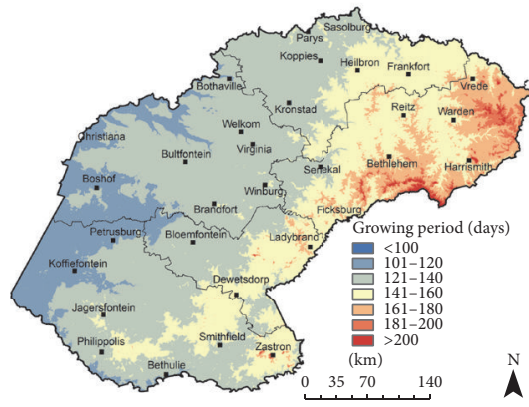

$\square$ District municipalities - Towns

(a)

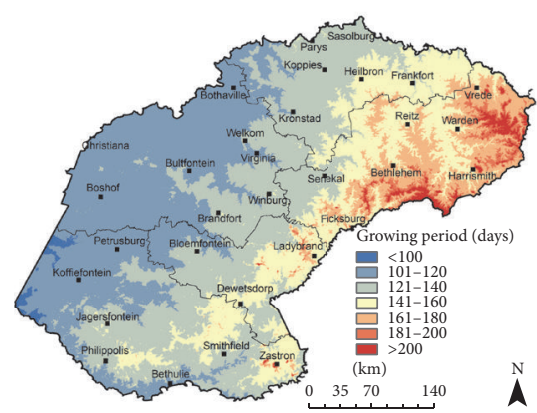

$\square$ District municipalities

- Towns

(d)

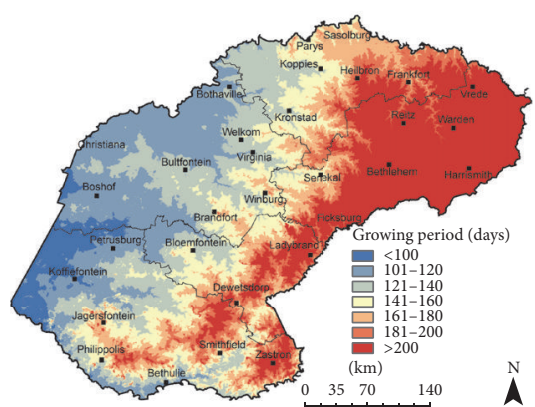

$\square$ District municipalities

- Towns

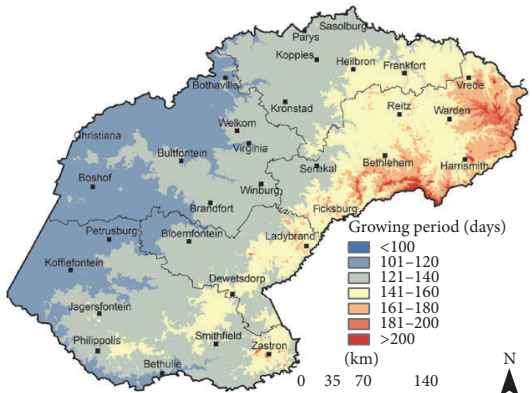

$\square$ District municipalities

- Towns

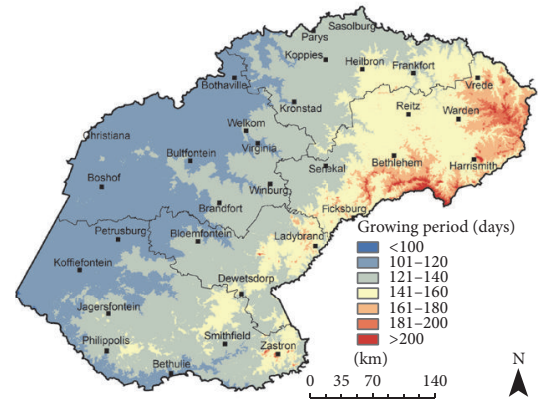

$\square$ District municipalities

- Towns (b)

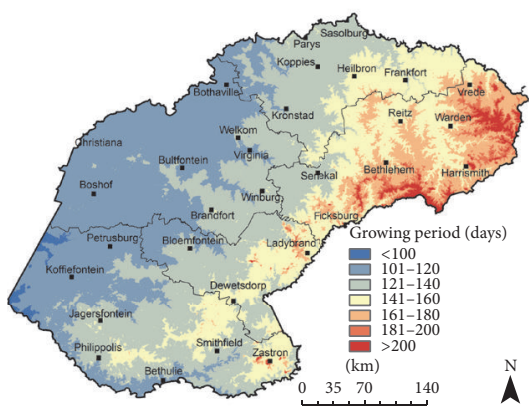

$\square$ District municipalities

- Towns

(e)

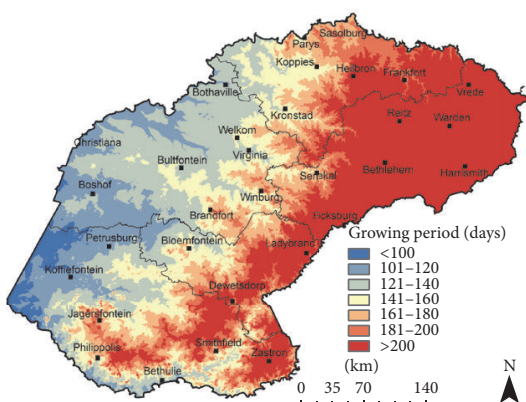

$\square$ District municipalities

- Towns

(h)

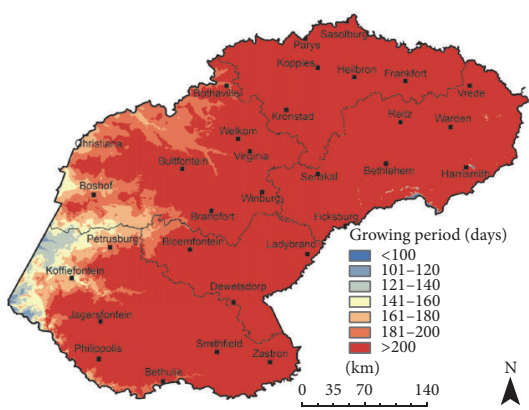

District municipalities

- Towns (c)

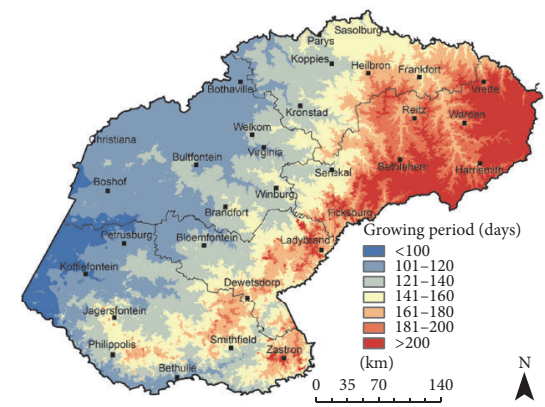

$\square$ District municipalities

- Towns

(f)

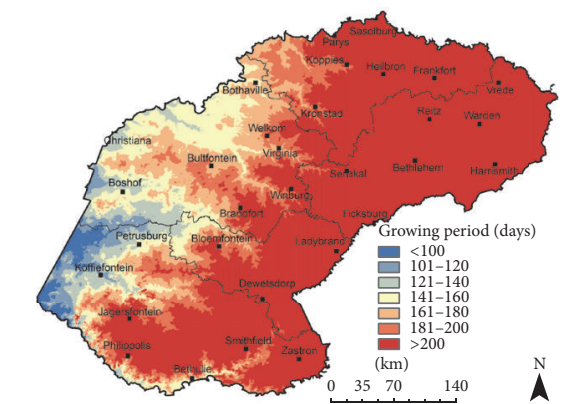

$\square$ District municipalities

- Towns

(i)

(j)

FIGURE 4: Growing period in days at $50 \%$ nonexceedence probability for a medium season maize variety planted in the (a) 1st dekad of October, (b) 2nd dekad of October, (c) 3rd dekad of October, (d) 1st dekad of November, (e) 2nd dekad of November, (f) 3rd dekad of November, (g) 1st dekad of December, (h) 2nd dekad of December, (i) 3rd dekad of December, and (j) 1st dekad of January. 


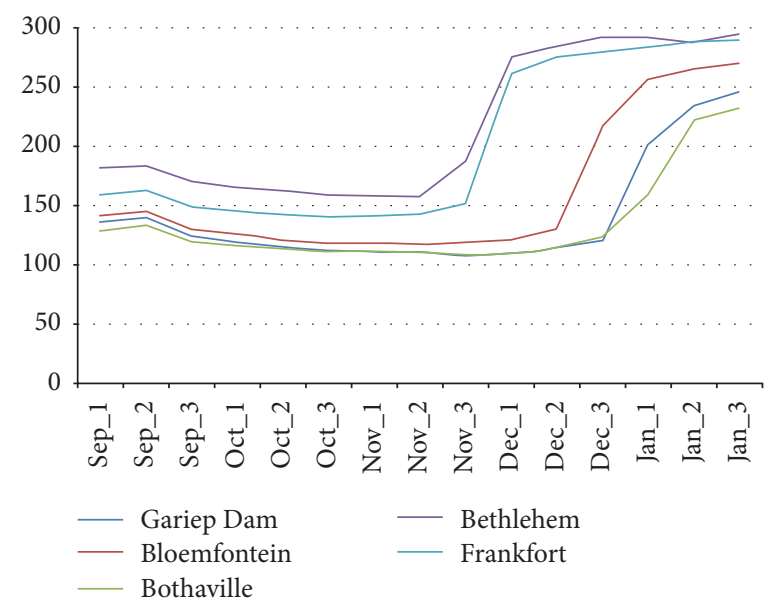

FIGURE 5: Length of growing period in days for a medium season maize variety for the Gariep Dam, Bloemfontein, Bothaville, Bethlehem, and Frankfort stations from the 1st dekad of September to 3rd dekad of January.

The durations of the growing period (days) that are needed to fulfil the heat units requirement for the short, medium, and medium-late season varieties show a great spatial variation over the province. Short season growing periods were very short where periods of less than 100 days were recorded for most planting dekads. A medium season maize crop at these places can grow for less than 100 days but the period can be up to 120 days. A medium-late maize crop can grow for periods mostly between 101 and 120 days for most planting dekads. Planting a medium-late variety at these areas has an increased risk of crop failure (growing period expanding to periods after April) during the planting dekads in January onwards.

Most of the western parts of the Free State have growing periods for short maize varieties between 101 and 120 days for most planting dekads. After the 2nd dekad of December growing periods can extend to 140 days in these areas and in January onwards the period can extend to over 140 days, making some places more vulnerable to climate risks. The medium maize varieties over these places are expected to have a median growing period of between 101 and 120 days extending to 140 days in December onwards. After the 3rd dekad of December onwards growing periods can exceed 160 days for some places and the risk of crop failure for planting medium season maize increases tremendously, thus planting in this period is not recommended. The medium-late maize variety has a greater range of growing period in western, southern, central, and northwestern Free State ranging from 101 to 140 days. The growing period increases up to 160 days after the 3rd dekad of November especially over eastern Lejweleputswa. Great risk to production due to extended periods is experienced when planting a medium-late variety after the 1st dekad of December in most parts of the Free State. Planting in these periods coincides the grain-filling stages of maize with autumn season that is mostly characterized by high frost risk and high soil water deficits.

The northern and central parts of the province achieve their short maize variety heat unit requirements mostly between 121 and 140 days. The period can extend to 160 days in December onwards and from the 2nd dekad of December the growth of a short season maize variety is not advisable in these regions as it will have poor yield due to extended growing periods. The period required to fulfil the medium season maize variety ranges from 121 to 140 days and from the 1st dekad of December most parts of these regions experience extended growing periods subjecting the crop to high climate risks. The number of days to fulfil the heat unit requirements for the medium-late maize crop over these regions is mostly between 141 and 160 days. The period can extend to 180 days and above from the 3rd dekad of November onwards making it a high risk zone for planting a medium-late maize season over those regions.

Most parts of the eastern and northeastern Free State record a growing period of between 141 and 160 days for short season maize cultivars. The period can extend up to 160 days and above from the 2 nd dekad of November onwards with increased risk of crop failure on and after the 1st dekad of December planting. The growing period for the medium season maize cultivar is between 141 and 160 days extending to 180 days after the 1st dekad of November. Planting of this variety after the 2 nd dekad of November will result in crop failure caused mostly by high frost incidences. The mediumlate maize takes up to 180 days in this region extending to over 200 days in the 2 nd dekad of November. After the 1st dekad of November planting medium-late maize variety will cause the crop not to reach full maturity. The planting window for maize production is smaller in the eastern and northeastern Free State due to extended growing periods caused by relatively low temperatures, thus planting of short to medium season varieties is recommended. For these areas, medium-late to late season varieties would most likely not attain full maturity before the onset of the frost season and hence negatively affect the maize productivity.

Agricultural advisors and farmers are advised to take careful note of the thermal requirements of maize varieties before they are planted due to large variability in growing 


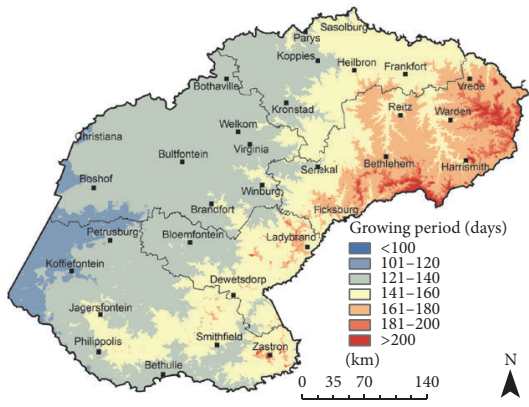

$\square$ District municipalities - Towns

(a)

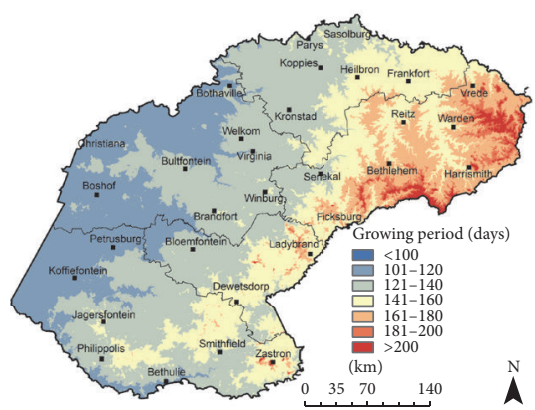

$\square$ District municipalities

- Towns

(d)

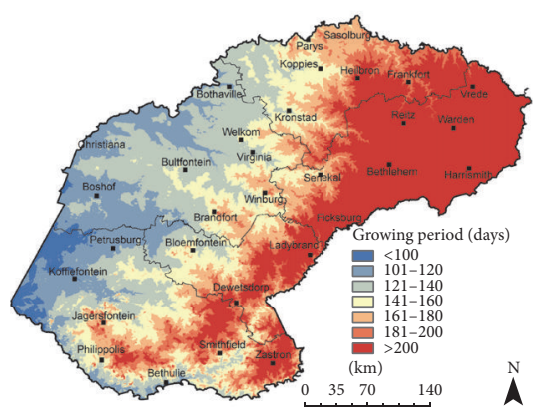

$\square$ District municipalities

- Towns

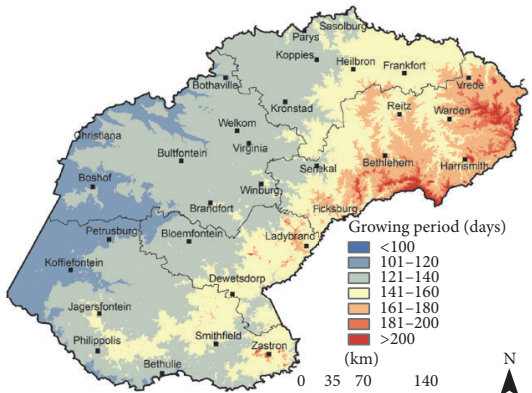

$\square$ District municipalities

- Towns

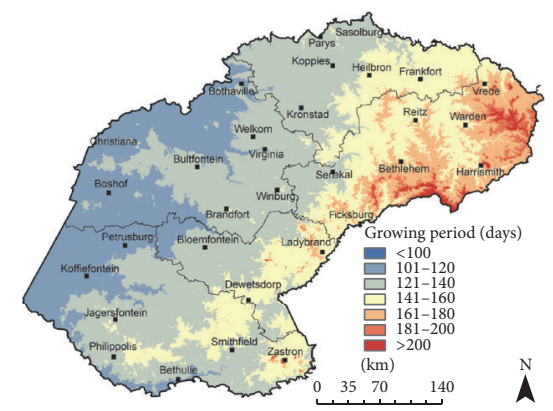

$\square$ District municipalities

- Towns (b)

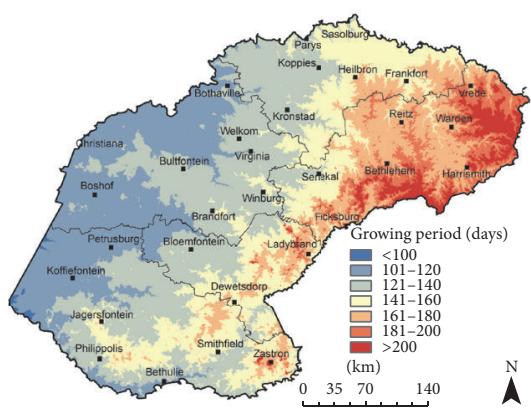

$\square$ District municipalities

- Towns

(e)

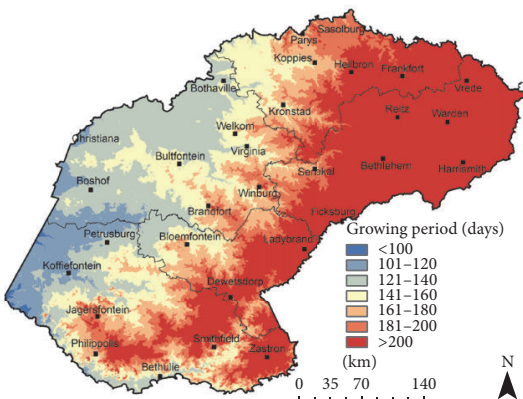

$\square$ District municipalities

- Towns

(h)

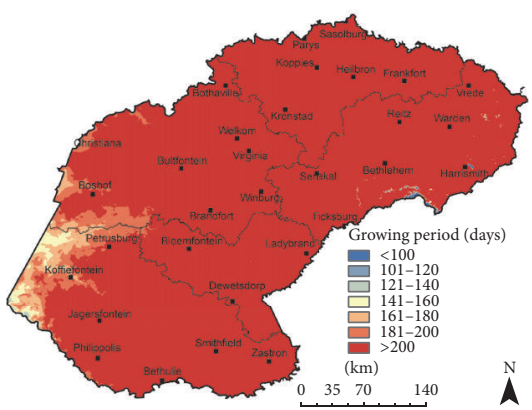

District municipalities

- Towns (c)

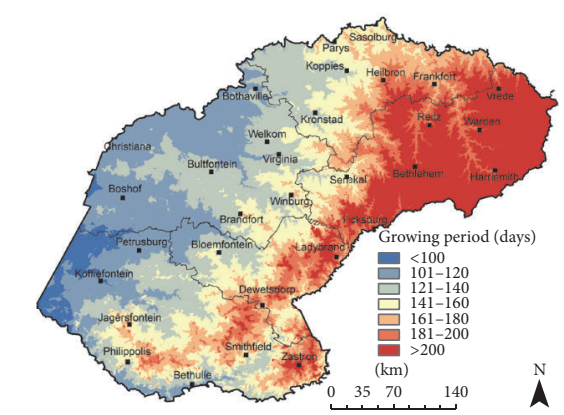

$\square$ District municipalities

- Towns

(f)

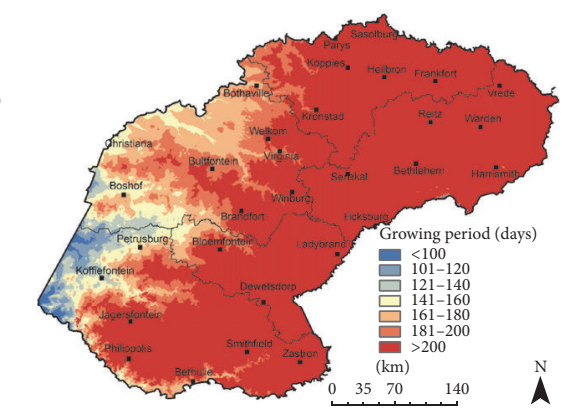

$\square$ District municipalities

- Towns

(i)

(j)

FIGURE 6: Growing period in days at 50\% nonexceedence probability for a medium-late season maize variety planted in the (a) 1st dekad of October, (b) 2nd dekad of October, (c) 3rd dekad of October, (d) 1st dekad of November, (e) 2nd dekad of November, (f) 3rd dekad of November, (g) 1st dekad of December, (h) 2nd dekad of December, (i) 3rd dekad of December, and (j) 1st dekad of January. 


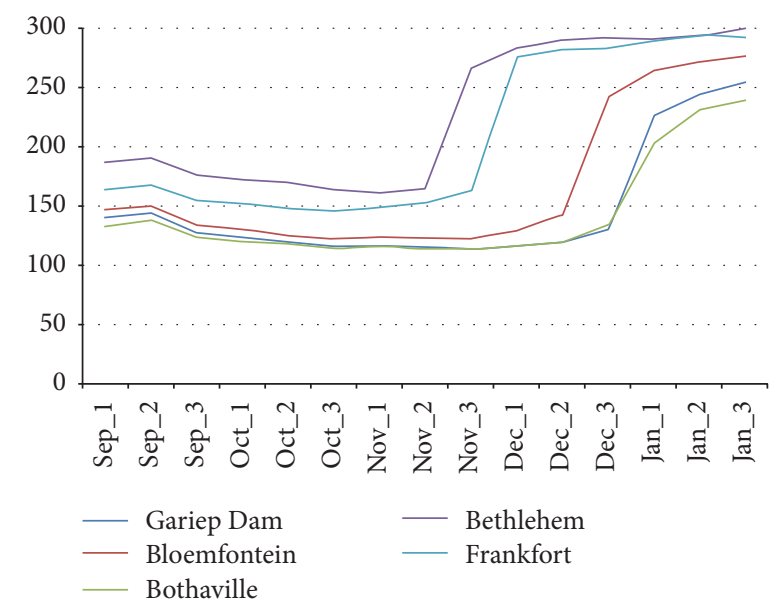

FIGURE 7: Length of growing period in days for a medium-late season maize variety for the Gariep Dam, Bloemfontein, Bothaville, Bethlehem, and Frankfort stations from the 1st dekad of September to 3rd dekad of January.

periods. Timing of sowing date is therefore crucial for optimal plant growth and development in areas that are prone to agroclimatological hazards.

\section{Conflicts of Interest}

The author declares that there are no conflicts of interest regarding the publication of this paper.

\section{Acknowledgments}

This study was supported by the Department of Agriculture, Forestry and Fisheries and Agricultural Research Council, Institute for Soil, Climate, and Water (Project no. GW57/007). Dr. Thomas Fyfield is thanked for editing the paper.

\section{References}

[1] M. K. Khushu, N. U. Rahman, M. Singh, A. Prakash, A. K. Tiku, and A. S. Bali, "Thermal time indices for some mustard genotypes in the Jammu region," Journal of Agrometeorology, vol. 10, no. 2, pp. 224-227, 2008.

[2] R. Gordon and A. Bootsma, "Analyses of growing degree-days for agriculture in Atlantic Canada," Climate Research, vol. 3, no. 3, pp. 169-176, 1993.

[3] F. C. Olivier and J. G. Annandale, "Thermal time requirements for the development of green pea (Pisum sativum L.)," Field Crops Research, vol. 56, no. 3, pp. 301-307, 1998.

[4] A. K. Singh, P. Tripathi, and S. Adhar, "Heat requirements for phenophases of wheat genotypes as influenced by sowing dates," Journal of Agrometeorology, vol. 10, no. 2, pp. 209-212, 2008.

[5] K. K. Agrawal and A. P. Upadhyay, "Thermal indices for suitable sowing time of chickpea in Jabalpur region of Madhya Pradesh," Journal of Agrometeorology, vol. 11, no. 1, pp. 89-91, 2009.

[6] X. B. Liu, X. Y. Zhang, Y. X. Wang et al., "Soil degradation: a problem threatening the sustainable development of agriculture in Northeast China," Plant, Soil and Environment, vol. 56, no. 2, pp. 87-97, 2010.
[7] J. I. Fisher, A. D. Richardson, and J. F. Mustard, "Phenology model from surface meteorology does not capture satellitebased greenup estimations," Global Change Biology, vol. 13, no. 3, pp. 707-721, 2007.

[8] P. Neog, J. Bhuyan, and N. Baruah, "Thermal indices in relation to crop phenology and seed yield of soybean (Glycine max L. Merrill)," Journal of Agrometeorology, part 2, pp. 300-392, 2008.

[9] D. M. Brown and A. Bootsma, "Crop heat units for corn and other warm season crops in Ontario," OMAFRA Factsheet, 1993, https://www.uoguelph.ca/plant/research/homepages/ ttollena/research/assets/Crop\%20Heat\%20Units\%20for\%20Corn\% 20and\%20Other\%20Warm-Season\%20Crops\%20in\%20Ontario .pdf.

[10] G. Sreenivas, R. Devender, and D. R. Reddy, "Prediction of phenology in aerobic rice using agromeeorological indices," Journal of Agrometeorology, no. part I, pp. 111-114, 2008.

[11] G. S. McMaster and W. W. Wilhelm, "Growing degree-days: one equation, two interpretations," Agricultural and Forest Meteorology, vol. 87, no. 4, pp. 291-300, 1997.

[12] M. Ruml, A. Vuković, and D. Milatović, "Evaluation of different methods for determining growing degree-day thresholds in apricot cultivars," International Journal of Biometeorology, vol. 54, no. 4, pp. 411-422, 2010.

[13] A. Bootsma and M. Suzuki, "Critical autumn harvest period for Alfalfa in the Atlantic region based on growing degree-days," Canadian Journal of Plant Science, vol. 65, no. 3, pp. 573-580, 1985.

[14] P. Kumari, A. Wadood, R. S. Singh, and R. Kumar, "Response of wheat crop to different thermal regimes under the agroclimatic conditions of Jharkhand," Journal of Agrometeorology, vol. 11, no. 1, pp. 85-88, 2009.

[15] L. M. Dwyer, D. W. Stewart, L. Carrigan, B. L. Ma, P. Neave, and D. Balchin, "Guidelines for comparisons among different maize maturity rating systems," Agronomy Journal, vol. 91, no. 6, pp. 946-949, 1999.

[16] M. P. Bange and S. P. Milroy, "Timing of crop maturity in cotton. Impact of dry matter production and partitioning," Field Crops Research, vol. 68, no. 2, pp. 143-155, 2000.

[17] J. Ransom, D. Franzen, P. Glogoza et al., Basics of Corn Production in North Dakota, North Dakota State University, Fargo, ND, USA, 2004, http://www.ag.ndsu.edu/pubs/plantsci/rowcrops/a834w.htm.

[18] Y. Arazi, S. Wolf, and A. Marani, "A prediction of developmental stages in potato plants based on the accumulation of heat units," Agricultural Systems, vol. 43, no. 1, pp. 35-50, 1993.

[19] Pannar, 2010 Product Catalogue, Pannar SA Head Office, Greytown, South Africa, 2010.

[20] P. Van der Walt, Personal Communication. Estimate Heat Units Required to Reach Maturity for Different Pannar Seeds, Pannar Head Office, Greytown, South Africa, 2010.

[21] R. E. Schulze, M. Maharaj, M. L. Warburton et al., "South African Atlas of climatology and agrohydrology," Report TT 82/96, Water Research Commission, Pretoria, South Africa, 2007.

[22] M. E. Moeletsi, Agroclimatological risk assessment of rain-fed maize production for the Free State Province of South Africa [Ph.D. thesis], Department of Soil, Crop and Climate Sciences, University of the Free State, Bloemfontein, South Africa, 2010.

[23] M. E. Moeletsi, S. Walker, and W. A. Landman, "ENSO and implications on rainfall characteristics with reference to maize production in the Free State Province of South Africa," Physics and Chemistry of the Earth, vol. 36, no. 14-15, pp. 715-726, 2011. 
[24] J. van den Berg, C. Manley, and H. Strauss, "Climatic suitability and production risk for selected agricultural commodities in the free state," Report Prepared by EnViro Vision, Free State Department of Agriculture, Bloemfontein, South Africa, 2002.

[25] M. E. Moeletsi, M. Tongwane, and M. Tsubo, "The study of frost occurrence in free state province of South Africa," Advances in Meteorology, vol. 2016, Article ID 9586150, 9 pages, 2016. 

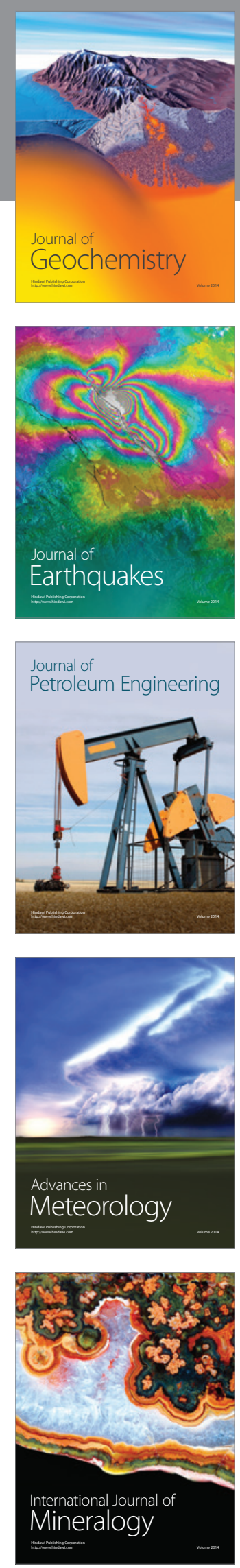
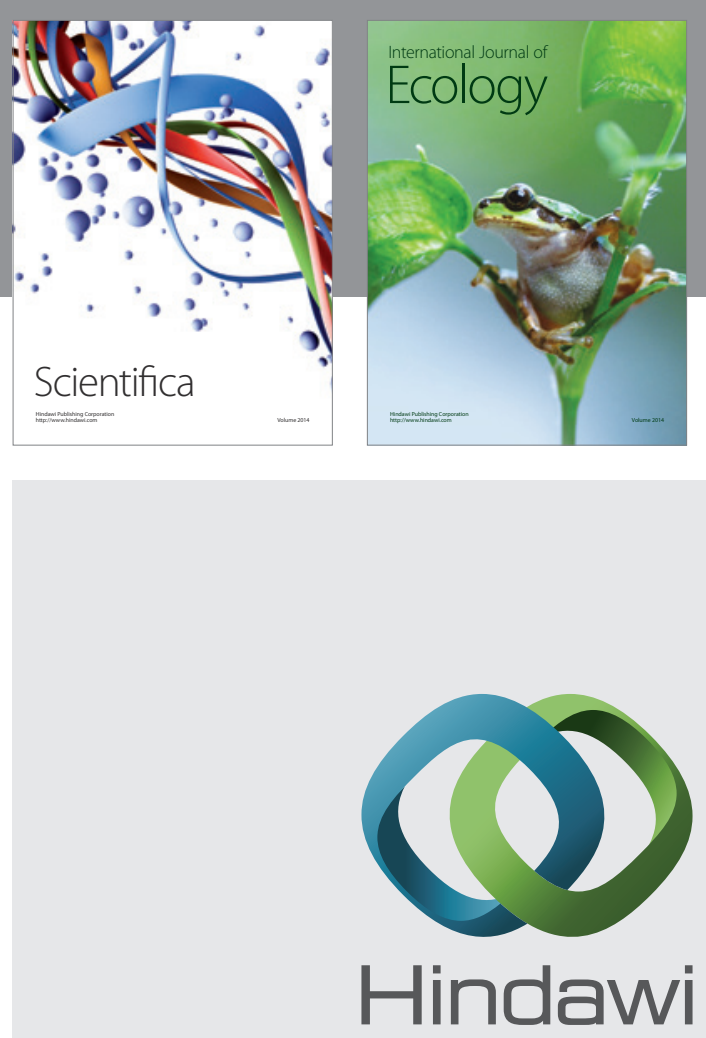

Submit your manuscripts at

https://www.hindawi.com
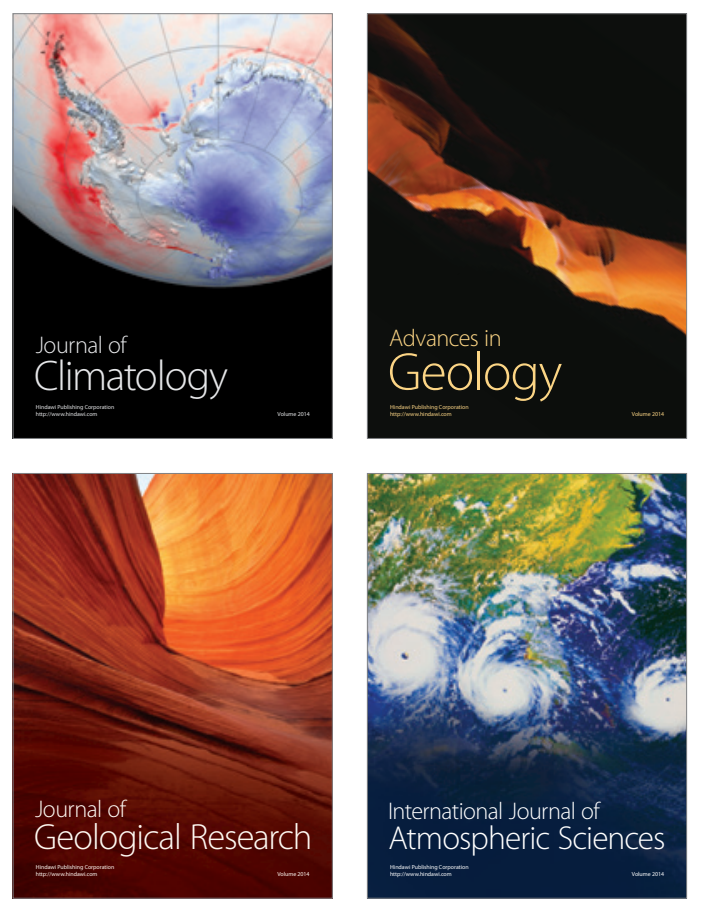

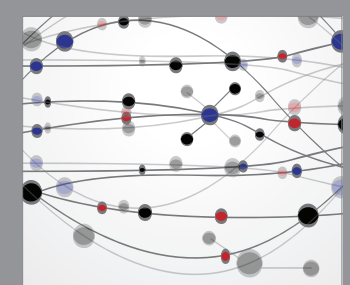

The Scientific

\section{World Journal}
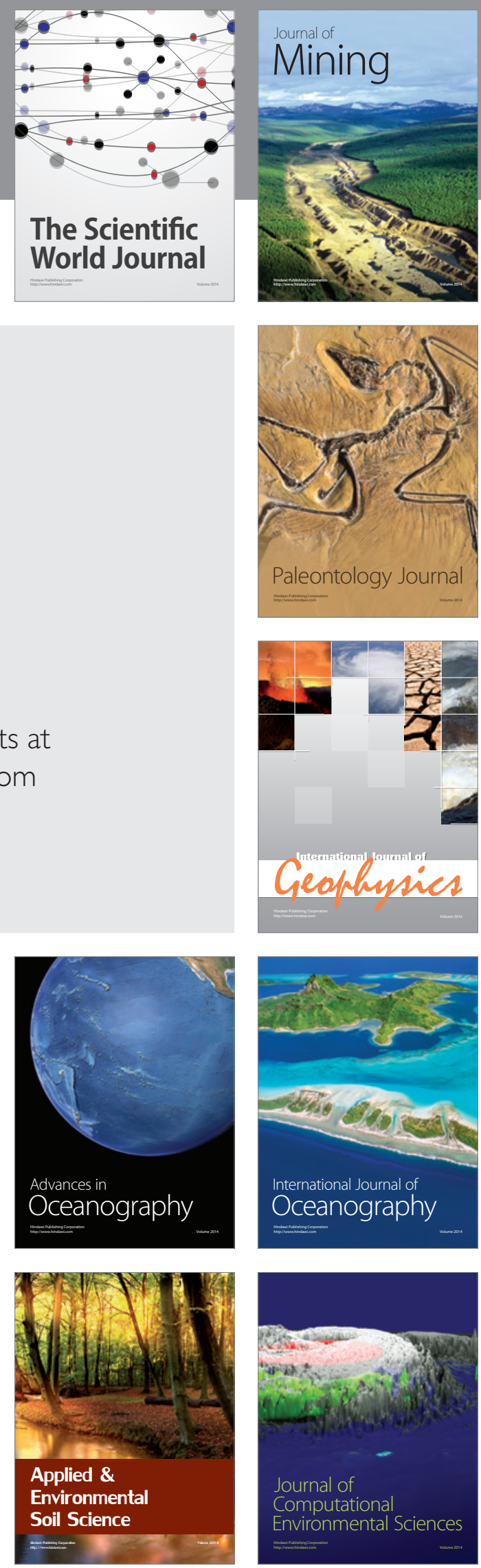